\title{
JURISPRUDENCE AND METAPHYSICS- A TRIANGULAR CORRESPONDENCE
}

\author{
$\checkmark$ HESSEL E. YNTEMAT
}

EASILY the most significant development of legal science in the United States during the past half century has been the Copernican discovery that law is a practical science. Or in other words, that law is not merely a static philosophy of justice enshrined in learned tradition but a dynamic enterprise of social control.

This conception has motivated the outstanding efforts to improve the content of the system of legal education. Most immediately, it implies recognition, on the one hand, of the critical importance of legislation as the chief modern technique for the determination and definition of social objectives and, on the other hand, of the crucial relevance to justice of the nature and effectiveness of the processes employed to realize the mandates of social policy. It further requires, as a basis for the critique of prevalent values and current procedures, the accumulation of adequate, validated, and pertinent information concerning the actual operation and effects of the administration of justice, as well as with regard to the living law and the economic, political, or social activities which the law purports to coordinate or control. Ultimately, as a means to compensate for local or ephemeral, national or cultural, biases, the conception of law as a means to attain social ends paves the way to an objective, humanistic scheme of legal science, to which the phenomena relating to the functioning of law in all times and places may be relevant. For, in the last analysis, the pragmatic approach is scientific, rather than traditional, dogmatic, or provincial, in outlook.

This expansion of the scope of legal education and legal science beyond the ancient boundaries of authoritative doctrine has in recent years fostered new philosophical perspectives, stimulated a variety of ventures in legal research, and, most conspicuously, occasioned a multiplication of more comprehensive casebooks to represent the enlarged subject matter in legal instruction. In this, growing, if not yet entirely adequate, attention has been focused upon the existent or possible procedures of the legal process in legislation and the administration of justice. In addition, there has come increased appreciation of the intimate relations between law and the other social sciences, but the tentative essays that have been made to establish lines of communication have as yet scarcely bridged the chasm that historically divides jurisprudence from social science. On the other hand, comparative legal studies, the significance of which has been latent in the

$\doteqdot$ Professor of Law, University of Michigan. 
burgeoning conception of legal science, have lagged. It remained for the last world war, exploding the myth of insularism and vastly extending the international commitments of the United States, to lift the horizon of interest in American legal education appreciably beyond the frontiers of national institutions, conceptions, and problems. From this point of view, the two-way program recently inaugurated at the Yale Law School presages a more cosmopolitan attitude in the law schools.

While the need to adapt the legal system of the United States to the social and economic requirements of the modern world was most persuasively reflected, at least for the past generation, in the sociological jurisprudence of Roscoe Pound, undoubtedly the primary credit for the progressive efforts that have been made to reform the historically oriented legal curriculum of thirty years ago in the light of this need belongs elsewhere. It was at the outset no light enterprise to convince the conservative law school community that legislation is a vital subject for legal study; that not alone legal doctrine but also its effective operation must be considered in legal instruction; that corresponding attention must be given to the practical aspects of judicial procedure and administrative law; that the interrelations between law and business practice, between legal and other social sciences, must be explored; that complementary comparative legal inquiries and notably actualistic studies to fill in the wide gaps in the available knowledge of the operation of the legal system, should be encouraged; in fine, that the study of law in the university law schools should be raised to a level of scientific activity comparable to that in other departments of education. The accomplishment of these objectives-which are even yet by no means adequately realized or even accepted in all quarters - was initially. due to the enlightened conviction and courageous persistence of a small group of legal scholars who in the 1920's launched the first comprehensive survey of the legal curriculum at the Columbia University Law School, an event which catalyzed the progressive efforts that have since been made there and elsewhere, abortively at The Johns Hopkins University, more effectively at the Yale Law School, and eventually in an increasing number of other institutions, to develop legal research and to provide a more modern and realistic system of legal education.

In this group, specifically concerned about the actual effects of law and profoundly imbued with the open-minded spirit of scientific inquiry, Underhill Moore was outstandingly influential. It was my good fortune to make his acquaintance during the period of curricular discussion at Columbia and thereafter as occasion offered to observe his rare qualities as a friend and as a student of law, his unfailing interest in legal education, his courageous convictions, and particularly the objective operation of his highly incisive and widely informed lawyer 
like mind. It is but just on this occasion to record the leading part that by virtue of these qualities he played in the critical stages of the movement to liberalize legal education in the United States, to which reference has been made, no less than his "fierce" devotion to legal education and his unflinching integrity as a legal scholar. For him, the results of careful research were their own best justification.

This integrity underlay the painstaking efforts that Underhill Moore made to establish an institutional technique for the study of the problems of law. It also explains a cardinal point in his views of such matters, namely, that as the cause of legal education is to be advanced by dispassionate objective inquiry, that cause may be prejudiced by unverified theory or irresponsible propaganda. The correspondence which follows these preliminary remarks canvasses an issue quite germane to this point, namely, the question of the relevance of metaphysical analysis to jurisprudence. And it may be observed in passing that the discussion is in a quasi-Socratic form that Underhill Moore presumably might well enjoy. Although those concerned have graciously consented to the publication of these letters, they have preferred anonymity. Nevertheless, they do exist, although not, as one explains, "for Descartes' reasons." One, the villain in the piece who instigated the exchange, is a veritable arbiter elegantiarum in matters of law, philosophy, and art; the other is a noted professional philosopher, who has published various recognized works in his field. Their respective contributions to the discussion of a most serious problem of intellectual cooperation concerning jurisprudence are gratefully acknowledged.

\section{CoRrespondence, MAY, 1941-January, 1942}

From $\mathrm{Y}$ to $\mathrm{H} \quad$ May 27,1941

A copy of the current Michigan Law Review containing my "Jurisprudence on Parade"[1] was forwarded to you under other cover about three

[1] 39 MrCH. L. Rev. 1154 (1941).

days ago. I await with apprehension the blast that may denote your ceasing to hold your breath, and with impatient interest your general reaction.

\section{From $\mathrm{H}$ to $\mathrm{Y}$ June 11,1941}

I sent a photostat of your paper to a friend of mine who is a professional philosopher and who has written a number of books on metaphysics and related subjects. He replied as follows:

"I am leaving tonight for the Cape, but I just want to write you that I 
have read Yntema's article with great interest and with pleasure at finding what he says about your book. He writes very well, but I am still puzzled by his use of the term 'realism' in the earlier part of the paper. By realism Yntema means-nominalism, e.g., page 1171, where 'law as fact' is described as 'ultra-realistic.' He evidently means something like actualism or materialism by the term. Of course, this is true also of the usage of a great many modern philosophers. For example, there is the term 'physical realism' which really means a kind of materialism or actualism. I judge that for Yntema there are two philosophical positions with respect to jurisprudence: ( 1 ) idealism or mentalism, with which he associates the name of Plato, and (2) 'realism', or building upon the brute facts which we have to face in actuality. I don't find true metaphysical realism as an alternative in his mind at all. I am anxious to know whether I am misunderstanding the legal theorists, which is, of course, quite possible."

I have explained to him what I thought you meant by realism, but if you want to send me your own statement, I should be delighted to pass it on to him.

\section{From $\mathrm{Y}$ to $\mathrm{H} \quad$ June 27,1941}

...

Second, the comment of your unnamed philosophical friend is of considerable interest, and I should have to grant him justice in remarking the inappropriateness of the term "legal realism," particularly since I have suggested as much myself. I should not want to respond to the comment, since I am sure that you have more than adequately done so. Moreover, on page 1156 you will find a humble effort on my part to epitomize the chief trends of the movement, though not in philosophical terms. But I believe the thought might be added that I don't believe that the so-called "realist" movement significantly developed in terms of any formal philosophical position. In fact, I should go further and allege that the realist program is quite congrous with a nominalist theory of knowledge, with a "true metaphysical realism," with certain species of idealism, as well as with pragmatism, if that be deemed a philosophy. In other words, I do not apprehend that the "realist" development derived from any specific philosophical theory of knowledge; the issue, as I see it, was between those who conceived that the solution of legal problems is to be found in the intuitive or logical application of general principles, evidenced by tradition or authority, and those who asserted that in the process the social aspects of the problems which the law is called upon to solve shotild be taken into account and the social policies involved and their consequences, as well as the means of giving them effect, systematically considered. In this persuasion, though the issue might be interpreted as one of transcendentalism vs. non-transcendentalism, it has not, as you know, seemed to me advantageous to analyze the situation further in epistemological terms. 
I should add only that, though there is some warrant in some of the realist literature for your correspondent's description of "realism" as "building upon the brute facts which we have to face in actuality," I should personally not accept the definition, at least unless there had been a thorough understanding as to what "brute facts" are.

\section{From $\mathrm{H}$ to $\mathrm{Y}$ July 9, 1941}

I am taking your letter with me to Nags Head where I shall ponder upon it by the seashore. I am afraid the complexities of the points you raise may preclude our discussing them by correspondence. Maybe the change of environment will suggest a method of simplification. Meanwhile, I passed your remarks in your letter of June 27 th on to my philosophical friend, who replies as follows:

"Mr. Yntema's remarks are interesting. He has two arguments in the passage you quote, and these finally reduce to one. (1) He denies that the realist movement in jurisprudence derives from any philosophical position. In this I have no doubt he is correct; but he seems to have misunderstood my comment and in so doing has fallen a victim of the familiar error of the confusion of history with logic, more particularly, of the confusion of that particular part of history which is psychological history, with logic. There is not even a faint family resemblance between the meanings of 'derived from' and 'implied by.' The realist movement in jurisprudence did not have to be derived from philosophic nominalism to be implied by it. For every theoretical position implies its own deducibility from some metaphysics, quite irrespective of consciousness and in fact of all history. My point was simply that the so-called realists in jurisprudence are the equivalent of nominalists in philosophy. Since I hold that nominalism as the whole truth, that is as the basis of an ontology and an epistemology, is false in philosophy, philosophy being superior in the theoretical field to jurisprudence, it follows that 'realism' in jurisprudence by deduction must be (held by me, at least), to be false as well. This leads inevitably into a second point.

"(2) At the bottom of your first paragraph, Yntema has pointed out that the issue is between two schools of jurisprudence; those who appeal to an application of principles, and those who appeal to actual social practices, and is thus internal to jurisprudence. Of course it is. Every field has internal problems which are yet related to metaphysics above and to actual experiences below. Things can only be related which are distinguished; and if jurisprudence did not have its own problems which make it in a sense independent of other fields, it would not have any real identity which could be related to other fields above and below. Any valid field, i.e. any empirical field capable of being investigated at its own level, will have to satisfy in the end both inferior practice and superior theory.

"This brings me to a last and to me most absorbing point. By stating 
the issue in jurisprudence the clear way he has, Yntema has also suggested its solution. There are two chief steps in logicouscientific method: correspondence and coherence. Correspondence is the check against factual actuality: is the hypothesis allowed by practice? Coherence is the check against existing theory: is the hypothesis consistent with theory? Those who look for legal solutions in what the court does in fact are asking for correspondence; those who look to traditional principles are asking for coherence. A complete demonstration can no more leave out one step than it can leave out the other. I am not suggesting, however, that the legal problem is as simple as this. It seems to me that the realist legal theory as well as the others are misconceived, but since I am an amateur of the rankest sort in legal theory I hesitate to say so until I can do better (which I hope to do). Such legal correspondence is at once too vague and too literal; such legal coherence is too naive since it seizes upon traditional legal theory and sets that up as the legal theory when as a matter of record it consists in a host of conflicting theories with which no hypothesis could possibly prove itself self-consistent since it is not self-consistent without the hypothesis.

"The sum of this argument amounts to the claim that jurisprudence is dependent upon metaphysics as much as upon concrete experience, whether the legal theorists admit this into their professional problems or not, and, further, that legal theory in its conflicts bears a striking resemblance to the conflicts in philosophy and to scientific method in the philosophy of science. I do not think that this philosophical approach to jurisprudence has even been scratched. I say this despite Cohen and others who have dabbled in it, and with all the humbleness which recognizes the possibility that I may not prove to be the right philosopher for the task. Clearly, however, somebody who has no fear of being wrong will have to tackle the task."

\section{From $Y$ to $\mathrm{H}$, July $1 \%, 1941$}

I am delighted to have your letter of the 9 th, which adds a few more pages to our conversations with the anonymous. Your intended vacation at Nags Head excites my envy; our brief stay there at your kind suggestion reminds me that it is a charming place. I might suggest, however, if it were not so impertinent, that, to our recent epistolary discussion, there is a certain propriety in your choosing a spot so named. I refer not to the possible banal connotations of the genitive "Nags," but to its alleged history. Indeed, it suggests that, in the Egyptian darkness of my philosophical innocence, you are calculating that, by leading an anonymous stalking horse carrying a wavering light along the beach, you may lure me into the epistemological shoals which apparently abound along the North Carolina coast.

In any event, the comment you have transmitted is of no little interest. For one thing, I am struck by the circumstance that your anonymous meta- 
physical counsel leads to a position which is somewhat analogous to one I attempted to develop sometime since in the New York University Law Quarterly Review, albeit by a path that I cannot but consider in certain respects dubious and though I should prefer, as at present advised, to emphasize accuracy and economy of formulation rather than coherence as the theoretical criterion of theory in law. (Indeed, in law there seems question whether consistency of theory, except in terms sufficiently abstract to be denuded of significance, should be for all purposes assumed as desirable. And, perhaps, your notion of "disorder" as a concept to order the realm of law might be relevant on this point.)

But, apart from the above analogy, I suppose you quite realize and not without smug amusement that there is a rather fundamental disparity of views. Thus, with regard to the comment on my effort to explain why I was not interested to discuss the realist movement in philosophical terms, the argument thus far might be dialectized as follows:

Anon.: Your article is apparently philosophically naive; it does not clearly develop the logical implications of legal realism and seems not to be aware of the possible metaphysical positions from which realism should be criticized.

Y.: But I don't believe that legal realism derived from any particular philosophical credo. (Aside, sotto voce) Medoubts that the realist movement can be significantly discussed in such terms. Can't one have freedom in his metaphysics-be a nominalist, a critical realist, or even a liberal-minded idealist-and still subscribe to the essential trends of legal realism?

Anon.: You suffer from the familiar error of confusing history and logic. There is not even a faint family resemblance between the meanings of "derived from" and "implied by."

Thus far the dialogue has gone; presumably, my cue is:

Y.: But I was discussing "Jurisprudence on Parade." Are you suggesting that the metaphysical implications of legal realism were of substantial historical significance in the development of the movement? And the response might be constructed as follows:

Anon.: No, but I strongly suspect that legal realism is the equivalent in jurisprudence of the heresy of nominalism in philosophy. This concerns me as a philosopher, since in the theoretical field philosophy is superior to jurisprudence.

Y.: Well, well. And I had been assuming in my essay, Jurisprudentia vera philosophia.

And so we come to the principal issue which induced me to talie exception some ten years ago to Morris Cohen's assaults on the effort to develop a more "realistic" approach to legal problems, namely, the independent significance of traditional metaphysics for legal science. The assumption, of which I have thus far seen no adequate demonstration, that metaphysics is 
theoretically superior to jurisprudence for the purposes of jurisprudence, appears to me an anachronous vestige of the ancient claim of theology to govern the mundane as well as the spiritual world. I am not disposed to attempt to argue this fundamental issue in this letter, though I should perhaps add that, in my view, speculative theory, which is of course a vital part of scientific inquiry, is an integral, and not an independent or superior, aspect of the scientific process.

\section{From $\mathrm{H}$ to $\mathrm{Y} \quad$ August 6, 1941}

Here are some extracts from the most recent letter of my philosophical friend. I hope he is not driving you into a corner.

\section{(Enclosure)}

Your copy of Yntema's letter has arrived and I have read it with much interest. I can see in it humour and genuine graciousness, and yet, at the same time, a slight disinclination to continue the controversy. Both elements spur me on to get at the heart of our differences. I can share Yntema's feeling that we represent divergent viewpoints: all the more reason, I think, to state them in such a way that one of us may be able to perceive the error of his position. For I hold of course, and I believe Yntema does also, that if two propositions exist on the same level of analysis and are contradictory, one of them must be at least partly wrong.

Therefore I go on to assert that in Yntema's fanciful arrangement of our future dialogue he has assumed for the relation of metaphysics to jurisprudence the necessary resolution of the problem to two mutually contradictory and exhaustive alternatives. Apparently, in his view, either (1) jurisprudence is dependent upon metaphysics, or (2) jurisprudence develops independently of metaphysics.

If so, (1), jurisprudence has no real independence. Jurisprudence will have to take what metaphysics chooses to give: whatever jurisprudence is implied by a developed metaphysics is the proper jurisprudence of metaphysics. Both Yntema and I reject this alternative.

(2) On the second alternative, metaphysics has no important relevance to jurisprudence. Metaphysics has to take what jurisprudence chooses to give. Whatever metaphysics is implied by a developed jurisprudence is the proper metaphysics of jurisprudence. I reject this alternative, too, but I believe that Yntema does not.

Since he does not, my attack upon his position must include (a) an attack upon both (1) and (2) and a rejection (b) of the presupposition that these alternatives exhaust the possibilities, at this level.

With respect to the rejection of (1), obviously neither a proper jurisprudence (nor a proper anything else) can be arrived at by simple deduction from metaphysics. This, on the grounds that we can neither guarantee knowing the true metaphysics nor having made the true deductive steps. That is the historical fallacy of procedure. The logico-ontological fallacy consists in the proposition that no number of universals can yield a particular. 
In actuality, each unique thing contains something over and above the universal elements: a spatiotemporal reference, a surd, or, as Plato called it, a receptacle, the mere fact of the togetherness in time and space of those certain universals which do compose it. Thus unique things can never be deduced absolutely from their universals. Jurisprudence, being less general than metaphysics, and standing in empirical relation to it, can never be deduced from it.

With respect to the rejection of (2), if metaphysics has no important relevance to jurisprudence, then what reason is there to believe that it has relevance to anything else? It will have to take not only what jurisprudence has to give, but also what science, psychology, etc, has to give. This means that science could imply realism while jurisprudence implies nominalism, and so on. To accept this possibility without holding that one of the studies is in error, is to deny the validity of metaphysics, and the real existence of truth. Jurisprudence is an important topic, and if metaphysics has no relevance to it, so much the worse for metaphysics, which then becomes an insignificant study. I see no reason to believe this, and many overwhelming reasons to doubt it.

So much for (a). We now come to (b). Let us see where we are, at this point. We have rejected both (1) and (2). But if we can devise a third alternative not thus far described, it may be that we can discover the true relation between jurisprudence and metaphysics. We have asserted that jurisprudence has real independence of metaphysics but that metaphysics has important relevance to it. This brings us, quite easily as it seems to me, to a third possibility. (3) Jurisprudence can develop independently of metaphysics but must submit its conclusions to metaphysics. Metaphysics, in other words, cannot dictate the right path to jurisprudence which must find its own way; but metaphysics can point out when the wrong path has been taken. Its control is negative.

Yntema sees in my remarks the shades of an old controversy with M.R. Cohen. Let me hasten to disabuse him of the notion that I am setting up myself, or my metaphysics as an absolute authority. I see in his remarks, similarly the shades of an old controversy; one which I have had elsewhere with neo-Thomism. I maintain the superior claim of metaphysics over jurisprudence so far as the foundations and conclusions, and even method, of jurisprudence are concerned. But I deny the authority of my own claim as a metaphysician, or even of my own metaphysics, to any absolute authority whatsoever. What I say is merely my opinion with respect to metaphysics; no one and nothing gives me final authority. This is what the neo-Thomist metaphysicians cannot understand about themselves and their positions. I cannot speak for metaphysics beyond my capacity as an humble seeker after the metaphysical truth; in which capacity I criticize jurisprudence. If, therefore, Yntema were criticizing me, or my metaphysics, I could yield. But if he is challenging the authority of metaphysics itself, I cannot.

In conclusion, then, jurisprudence should develop its theories independently 
of metaphysics, but must be ready to submit its conclusions to that tribunal. For inasmuch as jurisprudence has meaning beyond its own field, it has relations which involve external theoretical considerations. In this latter field, metaphysics, alone, is competent to judge.

\section{From $\mathrm{Y}$ to $\mathrm{H} \quad$ August 12, 1941}

I have your exiguous letter of the 6 th, enclosing further comment by your philosophical friend. What extraordinary patience, what logical solicitude are therein exhibited? Incidentally, I note your remark about being driven into a corner; it has, to repeat an expression recently used by an eccentric acquaintance, a "slant" that engenders suspicions. Among, them is the thought that you may be having me on, that your quondam "friend" may be one of your alter egos, a quibblesome Mr. Hyde.

The comment is obviously painstaking and interesting. Among other things, the ground has apparently been shifted from the issue whether metaphysics is superior to jurisprudence to whether it has important relevance for jurisprudence. I say "apparently,", since metaphysics is also ascribed superior claims "so far as the foundations and conclusions, and even the method, of jurisprudence are concerned." This limits rather stringently the further concession that jurisprudence can develop independently-which is perhaps more significant.

I also find a little comfort in the suggestion that the claim of a particular metaphysician and even of his metaphysics to final authority (though such is asserted for "metaphysics itself") is denied. From which I deduce that the same may apply to any other particular metaphysical system. From which I further deduce that metaphysics is something like the Holy Grail.

Thus, I come to the reflection that we have wandered somewhat afield from the affairs of jurisprudence. For, on the assumption that it is proper for jurisprudence to develop independently of metaphysics (an assumption that I am disposed to accept for the purposes of argument, even if a bit unfairly, for the reason that it lines up with my predisposition in the matter), the question of the possible relations between metaphysics and jurisprudence would seem to be distinctively the concern of metaphysics. This would cast upon metaphysics the burden of showing its pertinence to jurisprudence. Which brings us precisely to where we started in this correspondence.

This is too brusque a conclusion, and, anyhow, I should not wish silence with respect to this latest comment to allow the supposition that I have granted or assumed what I did not. So, I crave your indulgence for a few brief comments in response to the argument of your "friend," offered by way of appendix to the above. They relate to the nature of the demonstration offered to determine the relation of metaphysics to jurisprudence, more specifically to its formality.

First, bearing in mind that it is entirely possible for a proposition to be false, in whole or in part, as well as true, in whole or in part, I must confess 
that the analysis suggested does not have on me the conviction of an axiom. For one thing, it is predicated upon the assumption that, of two divergent views, at least one must be partially in error. As to this, difficulties rush to mind. For example, suppose two propositions with regard to the same subject matter, e.g., a quantumn of water, the one, "This water is hot," the other, "This water is cold." Now, how is it possible to say that, of these two propositions, one must necessarily be partially in error, since they may both be true (or false, or partly so) from their respective frames of reference? This seems to me an entirely possible analogy to the situation with respect to metaphysics and jurisprudence. It may be quite appropriate for the jurist to regard metaphysics as having about as much relevance to legal inquiry as, let us say, religious beliefs, to seek to obviate biases therefrom derived if such matters cannot be quite excluded from his inquiry, and at the same time it may be quite suitable for metaphysics, regarded as an examination of scientific methods, to assume that legal method is comprized within its subject matter. In other words, it seems to me entirely possible that two contradictory and apparently mutually exclusive propositions about the relevance of metaphysics to jurisprudence, or vice versa, are both at once tenable.

Second, allow me to refuse the position imputed to me that the relations between metaphysics and jurisprudence must be resolved into two alternatives, (i) that jurisprudence is dependent upon metaphysics or (ii) that jurisprudence develops independently of metaphysics. (Why should your metaphysical counsel, producing a tertium quid, limit his arguee to a dichotomy?) The reason why this analysis appears to me unsatisfactory is in part suggested above, but in addition it seems to me insufficiently exhaustive, even as a statement of the logical possibilities, for other reasons than those adumbrated by your philosophical adviser. In addition to the possible relations enumerated in his advice, one might suggest by way of instance, (iii) metaphysics is dependent on jurisprudence, (iv) jurisprudence and metaphysics are interdependent (which my last letter suggested as a possible position, if metaphysics be defined as including the pure theory of law), (v) the relations are partially dependent and partially independent, in what respects to be further ascertained, (vi) the relation is one of function, coincidence, or whatnot, and not specifically of dependence, or (vii) we are talling about the relation of an undefined quid to an undefinable quiddity. And doubtless other possibilities, worthy of contemplation from a merely logical or postulational point of view, might be adduced. I adduce these, not as a reductio ad absurdum of the analysis in question, but to suggest that the factors of which it takes account are inadequate.

This leads me in the third place to a question which seems immediately pertinent to our discussion, namely, what is metaphysics for? I can see a possible function for metaphysics, as once suggested by Bertrand Russell, comparable to those of art or religion, namely, to satisfy the human instinct or acquired habit of abstract speculation. I can also see a real service that might 
be rendered by a comparative study of the varied types of human intellectuation, an effort to correlate and synthesize the methods and techniques in the varied branches of knowledge. This latter species of investigation might reveal anomalies in juristic theory as contrasted with those followed in other fields and thus lead to further critical inquiry. But, in either event and if only because it is somewhat remote, it would seem that metaphysics would not be in position to control the issues of particular scientific studlies; to do so, it would have to become jurisprudence or science, etc. At most, it would seem to be in a position to suggest, either "Here is something which pleases or does not please my system of abstractions" or "Here is something similar to, or dissimilar from, what has been developed in another branch of knowledge." All this suggests that, to demonstrate the relevance of metaphysics to jurisprudence, it is needful to indicate in some detail just how metaphysics can contribute to-or control-the results of a juristic study of a legal problem. Nota bene: I say not that metaphysics is irrelevant to jurisprudence; only that the burden is on those who assert its relevance to define just what the legal scholar must look to metaphysics for in the pursuit of his work.

Perhaps an example will suggest more fully what I am trying to say. Here, for example, is the doctrine of Erie RR. v. Tompkins, which I suppose it would be considered appropriate for a legal student to investigate. He might try to ascertain what the existent doctrine in a Holmesian sense is, or to determine what it ought to be. The question is in what immediate or significant respects, in addressing himself to such a matter, should the jurist also examine his metaphysical presuppositions in terms of realism, nominalism, etc. ? It is obvious that we need light on this matter, if metaphysics is relevant to jurisprudence in any such sense as your friend supposes. And, in defautt thereof, the only practical hypothesis for our jurist to take as a working assumption, is that formal metaphysics is no more relevant to his science than Protestantism. There may be all kinds of relations, but there is no indication that they have practical significance for the job in hand.

If I may indulge in a final observation, it is that the enclosure in your letter illustrates an attitude that I have seen exhibited on other occasions in metaphysical circles, namely, the apparent conviction that metaphysics is not sufficient in and of itself, that its very vocation must collapse, if its claims e.g., to control jurisprudence, should prove untenable. I have at times wondered about this and about the apparent concern of some philosophers to convince their adversaries of the error of their premises, a motive that is also evident in the enclosure. Is there underlying such attitudes a basic source of uncertainty? Or is there inherent in metaphysical speculation an clan argumentatif, a lust for argument which implies that a metaphysics can prove itself only by producing conviction? If so, I would suggest, as I did with respect to Mr. C.'s scheme for a synoptic legal philosophy that would eliminate the differences of jurisprudence, that it would seem most desirable to have divergent views, since otherwise there would be no scope for argument. 
This is a long and, I fear, a tiresome letter. Forgive me. I shall be as Catonic as you are, in my next.

\section{From $\mathrm{H}$ to $\mathrm{Y} \quad$ September 2, 1941}

Here is the latest communication of my philosopher friend. Internal evidence, if not the ideas, should long ago have satisfied you that I am not the author. I am beginning to think my book was written in vain. I asked the author of the letters, as you will observe from his first paragraph, if I could reveal his identity. The answer is apparently no. Some day, however, I hope to bring the two of you together. He is not a Washingtonian and your visits in the past have never coincided with his. Otherwise, I would have brought you both together. He is, however, a full-fledged professional philosopher with a row of books to his credit (or discredit if you don't like metaphysics).

(Enclosure) August 25,1941

I have your letter of August 15th together with the enclosure from Yntema. Contrary to his suspicions, I do exist, although not for Descartes' reasons. Although I am sure that I exist, you need not tell him who I am, since that is the part I am not so sure of myself. There is one clue, however. I remember slipping on the pavement when I was about fourteen, and falling on my head so that I was unconscious for several minutes. When $I$ awoke I did not know what time it was, and ever since then I have been writing poetry.

But now to get on with Yntema's letter. I can see no conflict or restriction between the right of jurisprudence to develop independently of metaphysics and its duty to submit its findings to metaphysics. The fact that jurisprudence may be governed by a higher principle does not control it in its development, does not, for instance, keep it from straying from the truth at times. Is it not better to compare metaphysics to the Kingdom of God than to the Holy Grail? It is within you-whoever and (far more important) whatever you are, animal, vegetable or mineral, as we used to say in our parlor games.

Good, we agree, then, that jurisprudence can develop independently of metaphysics, yet I cannot admit that this casts the burden of the possible relations between jurispradence and metaphysics upon metaphysics. MIy son is free to develop independently of me but must submit his decisions to me. And to the extent to which he is free to develop independently, this does not put the burden of the necessity for our agreement on me but rather on him. Again, I am free to develop independently of my country's laws, within limits, but this does not put the burden of my agreements with those lavs upon my country; on the contrary.

Let me at this point record an aside, in the hope that it will clear up something. Metaphysics, in my view, is a higher science; jurisprudence a lower. "Higher" and "lower" often imply a value-connotation of better and worse, which is not intended here. Higher does not mean better; and lower, worse. Higher means more theoretical; lower means more empirical. I do not hold 
metaphysics to be better than jurisprudence. I simply mean that it is more theoretical. And this kind of relation is relative, but absolute given the frame of reference. For example, jurisprudence is theoretical compared with the more empirical practice of law.

But to continue: In a sense we may say that jurisprudence is not related to metaphysics but rather it is metaphysics-the metaphysics of law. One cannot escape from metaphysics simply by escaping from metaphysicians.

Unfortunately, I cannot admit Yntema's refutation of my axiom of contra'diction. He argues that of the two propositions, "This water is cold" and "This water is hot," "how is it possible to say that one must necessarily be partially in error, since they both may be true (or false, or partly so) from their respective frames of reference?" I am not aware that I did. I said that this applied to two contradictory propositions on the same level of analysis. (See my letter of July 29, first paragraph). It is absurd to suppose, and outside all the logic I have ever read, that two particular propositions can be contradictory. Moreover, I have never heard of two positive propositions being considered contradictory. The contradictory of "This water is cold" is "This water is not-cold." Two requirements of contradictory propositions are that one of them must be universal and one negative. Cold and hot are not contradictories; they are contraries.

Quite logically, just as Yntema's argument (second paragraph on page two of his letter of August 12) follows from the above, mine does, too. He says, so to speak, that there are not only hot and cold, but also warm, etc., in his additional alternatives of $i$-vi. But the original propositions that I submitted were contradictories; his new ones are contraries. I said in effect that with respect to the dependence of jurisprudence upon metaphysics, either jurisprudence is dependent upon metaphysics, or jurisprudence is not dependent upon metaphysics. Their is no third alternative to a contradiction; all other alternatives require their own contradictories.

This question in general seems to Yntema to lead him to another one, and he asks, "what is metaphysics for?" I feel here a certain inflection and suspect that he meant to add "anyhow," and that this question comes as a cry from the heart rather than as a question from the head. He seems to like Russell's answer, that metaphysics satisfies the human instinct for abstract speculation, or, in other words, that metaphysics satisfies the instinct for metaphysics, rather a circular solution, and hardly suggestive of anything except the amusing picture of Russell revolving rapidly (as he often does) upon his own axis. His last book suggests that he is not content with his own scuttling of his own ship. Yntema's elucidation of Russell's definition suggests that he, too, regards metaphysics as something inside the minds of metaphysicians. If it were nothing more than that I could feel as Yntema must that perhaps metaphysicians are meddling when they consider the metaphysical role of jurisprudence. This is a view which implies subjective idealism. But I doubt whether Yntema feels the same way about jurisprudence, for example. I'll venture that he holds jurisprudence to have some real relevance 
to the actual world (which it no doubt has), and not merely to be the private thoughts of legal theorists. If he believes this, too, then of course he is a nominalist with respect to philosophy and a realist with respect to jurisprudence. We all frequently do that but surely it is inconsistent. But here I may be arguing unfairly for Yntema.

I wish that I could state briefly the role of metaphysics, what metaphysics "is for." It would require many volumes. I am not here avoiding a challenge: I have done it in several volumes myself. Certainly, however, although I am unfamiliar with the doctrine of Eric $R$. $R$. v. Tompkins, I suspect that metaphysics would be of little service here. Any doctrine argued by induction from a single instance must either be or not be consistent with the system of law under which it is an instance. Metaphysics can tell us nothing about this, about the subsumption of either particular cases or of general laws under laws still more general. This is for logic to aid in solving; not for metaphysics to solve.

As to Yntema's last arguments, that metaphysicians betray a "basis of uncertainty" and a "Iust for argument," I cannot answer them; with due respect and in all sincerity I can only plead guilty. It is true that I am uncertain; would that all metaphysicians were. Peirce once gave his blessing to the critic who accused him of not being absolutely sure of his own position. As to the lust for argument, was not this the guilt of Socrates?

\section{From $\mathrm{Y}$ to $\mathrm{H} \quad$ January 8,1942}

First, a note about the enclosure from your Socratic friend, which I have again looked through. It seems to me that we are still, as it were, looking at each other through peepholes or, to change the metaphor, we are struggling in the spiderwebs of words. So be it-I accept the proposition that there can be but one alternative contradicting a universal proposition. But this scarcely goes to the point that I was trying-vainly it would seem-to make, namely, that the relation between jurisprudence and metaphysics cannot properly be so analyzed. Or, to put it another way, the suggestion that jurisprudence is dependent on metaphysics seems to me a positive statement, quite analogous to the proposition that water is hot, and therefore liable to a number of contrary alternatives.

I think that I should add this. I have been genuinely interested in learning (perhaps too like Socrates) what significance metaphysics may have for jurisprudence in the very practical sense of ascertaining what aids or controls metaphysics may provide in the study of legal problems. This much I have thought it not unjust to ask of a professional metaphysicist who suggests that metaphysics is higher than jurisprudence. I gather that it is appropriate for jurisprudence to proceed independently, subject to visitation from the higher realm of metaphysics. This doesn't seem to me to give me the crumb of bread I was looking for, but I am content. 


\section{BIBLIOGRAPHY OF W. UNDERHILL MOORE}

\section{Books}

Cases and Materials on the Law of Bills and Notes. By Howard L. Smith and Underhill Moore. St. Paul: West Publishing Co., 1910. Pp. xv, Y56.

Cases and Materials on the Law of Bills and Notes. 2d ed. By Howard L. Smith and Underhill Moore. St. Paul: West Publishing Co., 1922. Pp. xvi, 84\%.

Cases and Materials on the Law of Bills and Notes. 3d ed. By Howard L. Smith and Underhill Moore. St. Paul: West Publishing Co., 1932. Pp. xiii, $96 \%$.

Cases and Materials on the Law of Bills and Notes. By Howard L. Smith and Underhill Moore. 4th ed. by Underhill Moore. St. Paul: West Publishing Co., 1941. Pp. 1xiv, $10 \%$.

Negotiable Instruments. (In American Law and Procedure. Chicago, 1913).

Handbook of the Law of Bills and Notes by Charles P. Norton. 4th ed. with an appendix containing the Negotiable Instruments Law. By Wm. Underhill Moore and Harold M. Wilkie. St. Paul: West Publishing Co., 1914. Pp. 732.

Illustrative Cases on the Law of Bills and Notes. A companion book to Norton on Bills and Notes (4th ed.). St. Paul: West Publishing Co., 1914. Pp. 263.

Notes on the Uniform Partnership Act. (In National Conference of Commissioners on Uniform State Laws, Uniform Partnership Act, 1018, pp. 582-90).

The Law of Commercial Paper, prepared in the Extension Division of the University of Wisconsin. Edited and prepared for the press by J. B. Read. New York: D. Appleton \& Co., 1918. Pp. 309.

The Law of Commercial Paper, prepared in the Extension Division of the University of Wisconsin. Edited and prepared for the press by J. B. Read. New York and London: D. Appleton \& Co., 1929. Pp. 309.

Materials Prepared for the Private and Confidential Use of the Students in the Course Bills and Notes, Given in the Columbia Law School in 1928. (Not published).

Legal and Institutional Methods Applied to the Debiting of Direct Discounts, by Underhill Moore and Gilbert Sussman (reprinted from 40 YALE L.J. (1931) ) and An Institutional Approach to the Law of Commercial Banking, by Underhill Moore and Theodore S. Hope, Jr. (reprinted from 38 YaLE L.J. (1929)). New Haven, 1931. Pp. 193.

A Statement of Accounting Principles. Prepared by Thomas Henry Sanders, Henry Rand Hatfield, and Underhill Moore. New York: American Institute of Accountants, 1938. Pp. 138. 
My Philosophy of Law. Credos of Sixteen American Scholars. Published under the direction of the Julius Rosenthal Foundation, Northwestern University. Boston: Boston Law Book Co., 1941. Pp. 321. (Includes articles by Joseph W. Bingham, Morris R. Cohen, Walter W. Cook, John Dewey, John Dickinson, Lon L. Fuller, Leon Green, Walter B. Kennedy, Albert Kocourek, etc.)

Law and Learning Theory: A Study in Legal Control. By Underhill Moore and Charles C. Callahan (reprinted from 53 YaLE L.J. (1943)). New Haven: The Yale Law Journal Co., Inc., 1943. Pp. vi, 136.

\section{Law Journal Articles, Papers, and Reviews}

What Constitutes a Contract? 63 Albany L. J. 411-19 (1901).

Significance of the Term "Contract" in Article I, Section 10 of the Constitution, 14 Kansas LAWYER 1 (1907).

Right of the Remitter of a Bill or Note, 20 CoL. L. REy. 749-65 (1920).

Rational Basis of Legal Institutions, 23 CoL. L. Rev. 609-17 (1923).

Interest on the Balances of Checking Accounts, 27 Cor. L. REY. 633-49

(192\%) (with Abraham Shamos).

An Institutional Approach to the Law of Commercial Banking, 38 YaLE L. J. 703-19 (1929) (with Theodore S. Hope, Jr.).

Legal and Institutional Methods Applied to the Debiting of Direct Discounts (with Gilbert Sussman).

I. Legal Method, Banker's Set-Off, 40 YALE L. J. 381-400 (1931);

II. Institutional Method, 40 YALE L. J. 555-75 (1931);

III. Connecticut Studies, 40 YaLE L. J. 752-78 (1931);

IV. South Carolina and Pennsylvania Studies, 40 YALE L.J. 928-53 (1931);

V. The New York Study, 40 YaLE L. J. 1055-73 (1931);

VI. The Decisions, the Institutions, and the Degrees of Deviation, 40 YALE L.J. 1219-50 (1931); and Appendix, 40 YALE L. J. 1251-72 (1931).

The Current Account and Set-Offs Between an Insolvent Bank and Its Customer, 41 Y ALE L. J. 1109-33 (1932) (with Gilbert Sussman).

The Lawyer's Law, 41 YaLE L. J. 566-76 (1932) (with Gilbert Sussman). Review of: Records of the International Conference for the Unification of Laws on Bills of Exchange, Promissory Notes and Cheques, Geneva, 1931. 18 A.B.A.J. 400-2 (1932).

Das Gesetz des Juristen, 8 Sociologus 385-400 (1932) (with Gilbert Sussman and C. E. Brand).

Legal and Institutional Methods Applied to Orders to Stop Payment of Checks (with Gilbert Sussman and C. E. Brand).

I. Legal Method. 42 YALE L. J. 817-62 (1933).

II. Institutional Method. 42 YALE L. J. 1198-1235 (1933). 
Drawing Against Uncollected Checks. 45 YALE L. J. 1-38 (1935) ; 45 Y ALE L. J. 260-92 (1935) (with Gilbert Sussman and Emma Corstvet).

Relationship between Legal and Accounting Concept of Capital. In Papress on Accounting Principles and Procedure 64-8 (1938), presented at the Fifty-first Annual Meeting American Institute of Accountants. New York: American Institute of Accountants.

Law and Learning Theory: A Study in Legal Control. 53 YALE L. J. 1-136 (1943) (with Charles C. Callahan). 


\section{THE YALE LAW JOURNAL}

\section{VOLUME 59}

JANUARY, 1950

Nuxrer 2

\section{EDITORIAL BOARD}

Donatd F. TuRner

Editor-in-Clicef

Norxsan Replich

Executive Editor

\section{ARNOLD HOFFMAN \\ LLEWELIYN P. Young \\ Comment Editors}

\section{Monroe S. Singer Case Editor}

Leo P. ARNaboldr, JR. RICHARD M1. FitzSIArMrons WIIZIAMI E. HEGARTY JANIES D. HIIBORN

\author{
EDWARD N. BENJA3IN \\ Article and \\ Book Review Editor
}

\author{
Wunnas D. Gism \\ Rrchard F. IcL \\ Note Editors
}

ANDrew AY. WoOd Managing Edilor

Gerald D. Katcher

DONALD L. MIEDLOCK

ARTHUR M1. MíchaELSON

Jeroure PREstoN, JR.

WHTTNEY N. SEYMYOUR, JR.

\author{
Miecris G. Survar \\ Elurotr E. Vose \\ RAYuso:d H. Yourig \\ Edgar A. Zngerax
}

$\begin{array}{lc}\text { MARE McMaHoN } & \text { Ronemr Mr. Cazot } \\ \text { Business Secretary } & \text { Student Business Mfonoger }\end{array}$

Susbscription price $\$ 5.50$ per year

This number, $\$ 1.00$

Canadian subscription price $\$ 6.00$ per year; Forcign, $\$ 6.25$ per year;

for prices on other issues inguire

The Yale Law Joumal Company, Box 401 Y Yale Station, Nwo Haien, Connecticut

\section{CONTRIBUTORS TO THIS ISSUE}

F. S. C. Northrop. B.A. 1915, Beloit College; MI.A. 1919, Yale University; M.A. 1922, Ph.D. 1924, Harvard University. Sterling Professor of Philosophy and Law, Yale Law School.

Max Radin. B.A. 1899, College of the City of New York; LL.B. 1902, New York University; Ph.D. 1909, Columbia University. Professor of Law, University of California. Member of the New York bar.

Ferm S. Coren. B.A. 1926, College of the City of New York; ML.A. 1927, Ph.D. 1929, Harvard University; LI.B. 1931, Columbia University. Formerly Assaciate Solicitor, United States Department of the Interior. Visiting Lecturer in Law, Yale Law School, and in Philosophy, College of the City of New York Member of the New York and District of Columbia bars.

Hessex E. Yntexra. B.A. 1912, M.A. 1915, Hope College; MI.A. 1913, Ph.D. 1919, University of Michigan; B.A. (Juris.) 1917, Oxford University; S.J.D. 1921, Harvard University. Formerly Professor of Law at Columbia, Johns Hoplins and Yale. Professor of Law, University of Michigan. 